Clinical Image

\title{
Presence of Cryoglobulins in Blood Smear
}

\section{Teunissen SF*, Ermens AAM and van Gammeren}

AJ

Department of Clinical Chemistry and Hematology,

Amphia Hospital, Netherlands

*Correspondling author: Sebastiaan F Teunissen, Department of Clinical Chemistry and Hematology,

Amphia Hospital, Breda, The Netherlands

Received: December 17, 2018; Accepted: February 11, 2019; Published: February 18, 2019

\section{Clinical Image}

A 69-year-old woman, formerly diagnosed with splenic lymphoma with villous lymphocytes, presented at our clinic for follow-up analyses of hematological parameters and M-protein quantification.

Because of a low leukocyte count $\left(1.3 \times 10^{9} / \mathrm{L}\right)$, an automated differentiation of peripheral blood was performed. Microscopic inspection of the blood smear showed large clumps and rouleaux formation (Figure 1A). These findings suggested precipitation of cryoglobulins. Cryoglobulins are usually a fraction of the M-protein component which precipitate at temperatures below $37^{\circ} \mathrm{C}$ and resolve after reheating the sample.

M-protein analysis was performed and a type-I cryoglobulin with an IgG-kappa component of $1.8 \mathrm{~g} / \mathrm{L}$ was identified (Figure 1B). Because of the protein precipitation, the sample was incubated at $37^{\circ} \mathrm{C}$ for 15 minutes, to resolve the clumps. Although the blood smear still showed tiny clumps after incubation (Figure 1C) the amount of M-protein was increased to $15.3 \mathrm{~g} / \mathrm{L}$ (Figure 1D).

Cryoglobulins in blood samples exposed to temperatures below $37^{\circ} \mathrm{C}$ may precipitate and result in significant underestimation of the M-protein concentration. Protein clumps may be an indication for cryoglobulinemia. Secondly, cryoglobulins may lead to incorrect platelet and red blood cell counts in automated blood cell counters. Maintaining the sample with cryoglobulins at $37^{\circ} \mathrm{C}$ until analysis is crucial for reliable laboratory results.
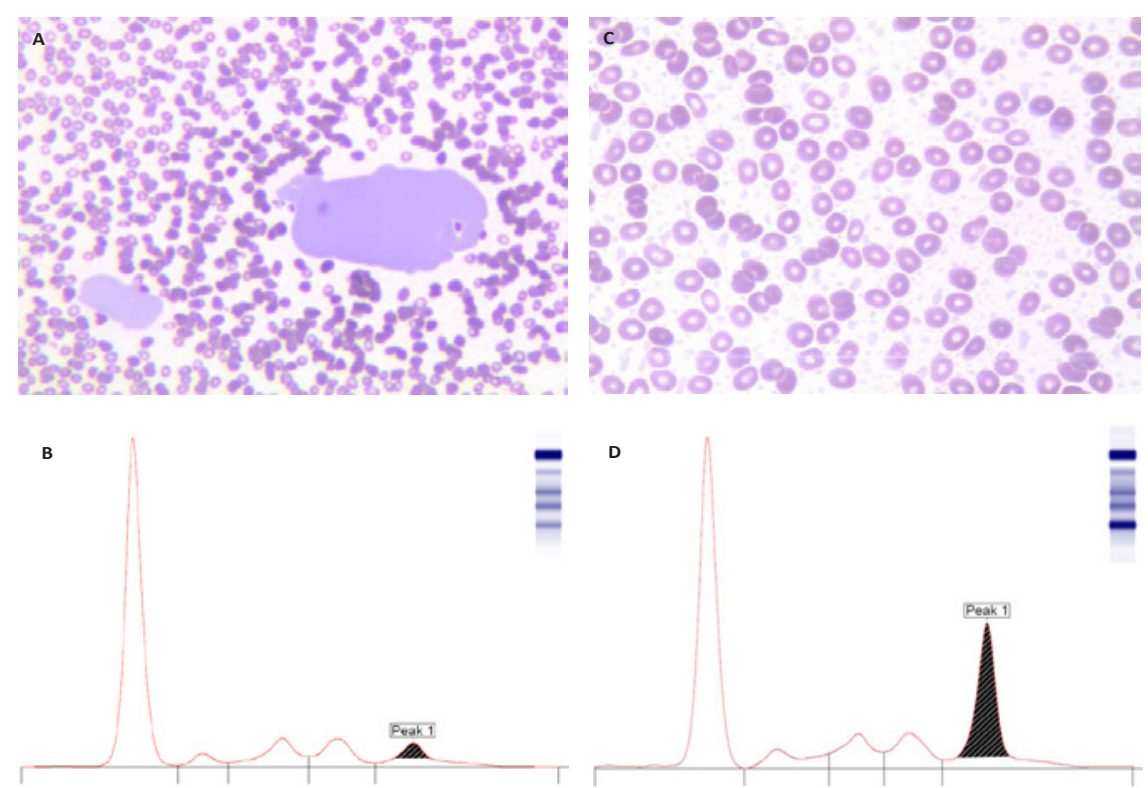

Figure 1: A) Blood smear with large clumps of cryoglobulins ( $\times 16$ objective), B) M-protein concentration of $1.8 \mathrm{~g} / \mathrm{L}$ measured at room temperature $\left(20^{\circ} \mathrm{C}\right)$, C) Blood smear with small precipitates of cryoglobulins after incubation for 15 minutes at $37^{\circ} \mathrm{C}(\times 63$ objective), D) M-protein concentration of $15.3 \mathrm{~g} / \mathrm{L}$ analyzed after incubation for 15 minutes at $37^{\circ} \mathrm{C}$. 